\title{
INFORMAÇÃO E MODOS CULTURAIS
}

É sempre produtivo e esclarecedor - também didático - tentar o entendimento das práticas informacionais através dos tempos, e para isto, há autores instigantes como Escarpit, Chartier, Deleuze e Foucault, dentre tantos outros. São autores que fornecem terreno teórico e nos dão pistas, nem sempre fáceis de seguir, a respeito do funcionamento de nossa sociedade. Pistas que, logicamente, evocam relações de espaço e tempo por onde e quando caminhou a sociedade até chegar aos nossos dias.

Como outras formas de expressão cultural, a informação se manifesta de vários modos. A comunicação e a informação, estão estritamente relacionadas às formas culturais manifestas, permitidas ou não, oficiais ou não de determinado grupo de indivíduos, de determinada nação ou país. Os modos de comunicar e informar são distintos nos vários períodos da história.

Antes da emergência da imprensa na Europa do Século XV, numa socieda- de de base oral e manuscrita, mesmo a escrita era privilégio de poucos. Entretanto, a imprensa não veio minimizar o analfabetismo daquela época. Somente no final da Idade Média, quando a Europa respira os ares do Renascimento, é que a educação começa, ainda muito timidamente, a ser chegar a classes menos abastadas.

Tratando-se da cultura escrita, durante quinhentos anos o livro manteve seu papel hegemônico em relação a outros suportes informacionais e as bibliotecas sempre foram depositárias do saber e da cultura, os grandes templos do poder. É interessante pensar que o livro é o primeiro produto cultural a entrar na era da reprodutibilidade técnica, antes mesmo da revolução industrial.

Mas é importante entender que, além de ser restrito aos que decodificam a escrita, o livro se impõe como um instrumento de diferenciação cultural dentro da própria cultura letrada. Livros existem para os que têm acesso ao saber erudito. 
Livros existem para os que apenas decodificam a palavra, mas não têm acesso ao saber especializado das ciências.

A Revolução Industrial acelera as técnicas de impressão e especialmente as técnicas de comunicação e documentação em formatos diferentes do impresso.

No Século XIX surgem a fotografia, o cinema, o telefone, o rádio, o fonógrafo, a célula fotoelétrica, o telégrafo elétrico. A todos estes desenvolvimentos, vêm se juntar, já no Século $X X$, a televisão, o telefone magnético, o cinema falado, o transistor.

Após a segunda grande guerra as mudanças tecnológicas iniciadas levam a sociedade a um processo irreversível de automatização que atinge todos os domínios, desde o ambiente da produção até o cotidiano doméstico. É um processo de integração informacional, de conexão das economias e dos indivíduos.

Pode-se dizer que, através dos tempos, ocorre o deslocamento da mate- rialidade do suporte da informação. A informação, antes mediada pelo documento, agora se desmaterializa. Outrora limitada ao suporte impresso, assume, no contemporâneo, suportes múltiplos.

É Chartier quem reflete com primazia sobre os papéis do autor-leitor nesta nova situação. Reportando-nos ao autor, podemos dizer que, na configuração atual dos processos informativos, além da maleabilidade do suporte, há a transmutação do autor, que se transforma também em editor e que se transfigura ainda em usuário da informação.

Esses fenômenos têm sido tratados com intensidade pela Ciência da Informação. E a cada fascículo a Informação \& Informação traz discussões importantes e necessárias para nossa área.

Leitor, aproveite o conteúdo de nossa revista. Autor, envie suas contribuições.

Boa leitura!

Terezinha Elisabeth da Silva

Editora 